\title{
Handaxe and non-handaxe assemblages during Marine Isotope Stage 11 in northern Europe: Recent investigations at Barnham, Suffolk, UK
}

\author{
Nick Ashton ${ }^{1 *}$, Simon G. Lewis ${ }^{2}$, Simon A. Parfitt ${ }^{3,4}$, Rob J. Davis ${ }^{2}$ and Chris Stringer ${ }^{3}$ \\ ${ }^{1}$ Department of Britain, Europe \& Prehistory, British Museum, 56 Orsman Road, London N1 5QJ, UK \\ ${ }^{2}$ School of Geography, Queen Mary University of London, Mile End Road, London E1 4NS, UK \\ ${ }^{3}$ Department of Earth Sciences, Natural History Museum, Cromwell Road, London SW7 5BD, UK \\ ${ }^{4}$ Institute of Archaeology, University College London, 31-34 Gordon Square, London WC1H OPY, UK \\ *nashton@britishmuseum.org
}

\begin{abstract}
Britain has an important geological, environmental and archaeological record for MIS 11, which makes a major contribution to understanding of the human occupation of northern Europe. New fieldwork at Barnham, Suffolk, UK, has identified through improved geological resolution, the change in assemblages from simple core and flake working to those with handaxe technology. The two assemblages are argued to reflect distinct human populations from different source areas in Europe. The paper examines the European record and puts forward a new model of how the complex mosaic of lithic assemblages reflects local, habitual practices during stable environments, but changes in climate and environment led to larger scale shifts in population, resulting in new human groups arriving in Britain.
\end{abstract}

Keywords: MIS 11; Europe; UK; Lower Palaeolithic; Hoxnian; Handaxe

\section{Introduction}

Research over the last two decades has improved understanding of the European geological and environmental record for Marine Isotope Stage (MIS) 11, 424-374 ka. In Britain several sites occur within basins formed on the surface of Anglian (MIS 12) tills that are infilled with fine-grained sediments containing rich organic remains. Of particular note is the palynological sequence for the Hoxnian Interglacial (Hol to HolV of Turner, 1970; cf. West, 1956), which has now been correlated with MIS 11c (Ashton et al., 2008, Candy et al., 2014). Molluscan evidence from Hoxnian sites has also been used to correlate sequences in East Anglia, the Thames Valley and Europe (Kerney, 1971; Preece and Penkman, 2005; Preece et al., 2007; Ashton et al., 2008; White et al., 2013; Candy et al., 2014; Limondin-Lozouet et al., 2015).

Several British archaeological sites can also be related to the environmental record of MIS 11. Early Hoxnian non-handaxe assemblages were argued to underlie handaxe assemblages at Swanscombe and Barnham (Smith and Dewey, 1913; Paterson, 1937); these non-handaxe assemblages were likened to those at Clacton and termed 'Clactonian' (Warren, 1926; Breuil, 1932). This led to the idea of more primitive early colonisers from Eurasia without evidence of handaxe use, followed by a second more technologically accomplished group with handaxes from southern Europe and Africa as part of the widespread Acheulian (Wymer, 1968; Collins, 1969).

Research in the 1980s and 1990s questioned the cultural interpretation of the British Clactonian and Acheulian, arguing that the only distinction between the assemblages was one based on negative evidence, namely the absence of handaxes. Functional differences, raw material variation and sample size were suggested to explain the absence of handaxes, resulting in a series of papers and Barnham was central to this debate (Ashton et al., 1994, 1998, 2005; McNabb, 1992, 2007; WenbanSmith, 1998; White, 2000; White and Schreve 2000). 


\section{East Farm Barnham}

The former brick pit at East Farm, Barnham ( $52^{\circ} 22^{\prime} 29^{\prime \prime}$, E $0^{\circ} 45^{\prime} 14^{\prime \prime}$ ), has been known to contain Palaeolithic archaeology since the early $20^{\text {th }}$ century (Whittaker 1891; Clarke 1913), with excavations in the 1930s and in 1979 (Paterson, 1937; Wymer, 1985; Fig. 1). Both excavations recovered nonhandaxe Clactonian assemblages, which they suggested underlay handaxes, based on earlier reports (Clarke, 1913). The uncertainty of the context of the handaxes led to fieldwork from 1989 to 1994 (Ashton et al., 1998).

The 1989 to 1994 fieldwork established that Pleistocene deposits occupy a glacial meltwater channel cut into Chalk bedrock and initially infilled with till (unit 1), sands and gravels (unit 2) and debris flow diamictons (unit 3 ). These are overlain by mainly fine-grained sediments, with lateral variations between the centre and the margins of the basin. At the edge of the basin these glacial deposits are overlain by a coarse lag gravel (unit 4), silt (unit 5e), black clay (unit 6) and brown silty clay ('brickearth', unit 7), all of which are decalcified. Micromorphological analysis indicates that unit 6 is a palaeosol, and a series of darker grey zones within unit 7 are interpreted as less distinct palaeosols (Kemp, 1998). The gravel (unit 4) thins out and the silt (unit 5e) thickens towards the centre of the basin, where it is calcareous, contains organic remains and is referred to as unit $5 \mathrm{c}$. Pollen, molluscs and vertebrates preserved in these sediments suggest a slow-moving to still body of water that gradually dried out, surrounded by grass and deciduous vegetation with slightly warmer summers than present (Parfitt, 1998a). The drying out of the basin was followed by soil formation (unit 6) succeeded by further infilling of the basin with brown silty-clays (unit 7) predominantly deposited as colluvium from the valley slopes. These deposits can be attributed to the Hoxnian interglacial on the basis of their stratigraphic position (Lewis, 1998), aminostratigraphy (Preece and Penkman, 2005), biostratigraphy (Parfitt, 1998b) and geochronology (Voinchet et al., 2015). The palynology of unit 5c suggests attribution to Holl (Hunt, 1998).

These excavations produced two substantial archaeological assemblages from separate locations 50 $\mathrm{m}$ apart on the southern margin of the basin within, on and slightly above the lag gravel, which was the source of raw material (Ashton, 1998). The assemblage from Area I consists of cores, flakes and flake tools, but with no handaxes or flakes from their manufacture. The fresh condition of many of the artefacts and refitting shows that most of the assemblage is in primary context, although some rolled material shows fluvial reworking of older cores and flakes. The assemblage from Area IV(4) was interpreted as being in an identical stratigraphic position to that from Area I and contained, in addition to cores and flakes, two handaxes and over 250 soft hammer flakes from their manufacture.

Smaller assemblages were recovered elsewhere at the site; in the middle of the basin hard hammer flakes and a core were associated with the vertebrate material, which included cut-marked bone. Within the palaeosol (unit 6) at the margins of the basin, one handaxe was found in Area I and over 50 handaxe manufacturing flakes in Area V. The published interpretation was that similar groups of hominins were using the resources of the basin over a period of time until the basin dried out, with occasional handaxe manufacture as raw material permitted or circumstance required their use. This argued against the succession of Clactonian then Acheulian cultural groups at the site (Ashton et al., 1994, 1998).

\section{New fieldwork at Barnham}

New excavations at Barnham since 2013 are re-examining the stratigraphic relationship between Areas I and IV(4) by opening a new area (Area VI) immediately to the west of Area IV(4) (Fig. 1C). This has enabled a more complex interpretation of the sequence to be offered. In the western part of Area VI the sequence is similar to that in Area I. Towards the eastern end of Area VI, units 5e and 6 thin and are absent at the eastern end of Area VI and in the adjacent Area IV(4), where unit 7 
immediately overlies the lag gravel (unit 4). Approximately $0.35 \mathrm{~m}$ above the lag gravel in Area IV(4) is a darker grey horizon, which was previously interpreted as the equivalent of unit 6 , but can now be shown to be a later phase of soil development within unit 7 and can be traced laterally into Area VI (Fig. 1C, Fig. 2). The transect through Areas IV(4) and VI coincides with a significant division in the lithic assemblages associated with the lag gravels. Where the gravel is sealed by units $5 e$ and 6 there is no evidence of handaxe manufacture, which only occurs where the gravel is directly overlain by unit 7. This is consistent with the single handaxe found in the palaeosol (unit 6) in Area I and the handaxe manufacturing flakes in the palaeosol (unit 6) in Area $V$, where they are both sealed by unit 7 (Ashton et al. 1998).

The reinterpretation of the stratigraphy suggests that either the surface of the gravel in Area IV(4) continued to be exposed during the deposition of unit 5e and development of unit 6 in Area I and in the western part of Area VI, or it was buried by these sediments which were then locally eroded, resulting in the re-exposure of the gravel surface. Burial and re-exposure are considered to be less likely as units $5 \mathrm{e}$ and 6 gradually thin out in the eastern part of Area $\mathrm{VI}$, with no evident erosional unconformity. The preferred interpretation is that the gravel in Area IV(4) was exposed for a longer period of time than the gravel in Area VI (west) and Area I.

The longer exposure of the gravel in Area IV(4) has produced a time-averaged assemblage, both contemporary and later than the assemblage from the gravel in Area I. A small, abraded component consists of simple cores and flakes, whereas the handaxe and handaxe manufacturing flakes are all in fresh condition with refitting material showing minimal disturbance. In combination, the fresh condition of the handaxe assemblage and its stratigraphic position immediately beneath unit 7 suggest that the assemblage is contemporary with the formation of the palaeosol (unit 6).

Establishing when the introduction of handaxes occurred within the interglacial succession can be inferred from the palynology signal from unit $5 c$ in the middle of the basin. The formation of unit 6 would have developed initially at the edges and then encroached towards the middle of the basin as the water body dried out. Although this implies that both assemblage types at the edge were potentially contemporary with unit $5 \mathrm{c}$ in Area III, the small lithic assemblage recovered to date from Area III only contains hard hammer flakes with no evidence of handaxe manufacture. This suggests that the non-handaxe assemblages from Area I and Area VI (west) are contemporary with unit $5 c$ in Area III, which spans Holl. It is unclear whether the handaxe assemblage from Area IV(4) can also be assigned to Holl or a later pollen zone.

The archaeological evidence from Barnham, in common with other Hoxnian sites in Britain, indicates a change in the archaeological signatures during or after Holl. Non-handaxe assemblages can be recognised at Barnham (Areas I and VI), Clacton (Freshwater Bed), Swanscombe (Lower Gravel and Lower Loam) and Southfleet Road, Ebbsfleet Valley (Wenban-Smith, 2013). This is followed by the introduction of handaxe technology, at Barnham (Areas IV(4) and V) and Swanscombe (Middle Gravels) (Fig. 3). These handaxe assemblages may be contemporary with handaxes from the tufaceous deposits (Bed 4) at Beeches Pit. The sudden introduction of fully developed handaxe technology, particularly at Barnham, suggests the arrival of new groups of hominins, rather than the in situ development of this technology. The two phases of hominin activity arguably reflect different cultural traditions of flint knapping practice that were introduced from Europe. The earlier suggestion of a land-bridge between Europe and Britain during MIS 11 (Meijer \& Preece, 1995) is now supported by evidence of a connection across the Southern Bight of the North Sea Basin (Hijma et al., 2012). This would have enabled movement of populations between Britain and the rest of Europe throughout MIS 11c, even at times of high sea level. To interpret the succession of human colonisers entering Britain during MIS 11c it is necessary to identify the possible source areas in Europe. 


\section{The European context}

Identification of potential source populations in Europe is hampered by issues of correlation between sites and comparisons of the archaeological assemblages. La Celle and St Pierre-les-Elbeuf (France) are both Acheulian sites dated to MIS 11 that have a distinctive suite of molluscs (Lyrodiscus fauna) also found at Beeches Pit in Britain, strongly suggesting that they are of a similar age in MIS 11c (Antoine et al., 2007; Preece et al., 2007; Limondin-Lozouet et al. 2010; Voinchet et al. 2015). Other than these, correlation is at best limited to the marine isotope stage, rather than sub-stage.

Equally problematic are the archaeological comparisons of British sites with those from mainland Europe, where the division into handaxe and non-handaxe assemblages is less clear. Fluck (2011) lists 108 sites from mainland Europe lacking handaxes, but only 14 have more than 50 artefacts and are of probable late Middle Pleistocene age with only four attributed to MIS 11 (Fig. 4). For most of the 14 sites, raw material is a limiting factor, where small pebbles of quartz or flint make handaxe production difficult, although it has been suggested that small bifacial points from Bilzingsleben should be regarded as handaxes (Mania, 1995). The distribution shows a preponderance of nonhandaxe sites in central Europe, but several can still be identified in France and Spain.

There is also complexity in handaxe assemblages with the identification of regional variants such as the 'Acheuléen Meridional' in southern France and Spain or the 'Acheuléen Septrional' in northern France. In Brittany in western France, handaxes are rare or absent in a further regional variant, the Colombanien (Molines et al., 2005), as is the case with some of the southern French sites, such as Arago (Barsky, 2013). Over the last three decades it has been recognised that much of the variation reflects raw material, site function or differences between the use of caves and open-air sites (Villa, 1991; Moncel et al., 2015). Despite the complexity in the assemblages, at a coarse level most handaxe sites tend to be in the west and south-west of Europe.

There have been suggestions that these broad lithic assemblage zones can be mapped on to variation in the hominin fossil record (e.g. Stringer, 2011) with early Homo neanderthalensis associated with handaxe industries at Swanscombe and the Sima de los Huesos at Atapuerca. In contrast the human fossils at Ceprano, Petralona, Bilzingsleben and Vértesszőlős have previously been attributed to $\mathrm{H}$. heidelbergensis (Stringer, 2012), and at least in the last two sites are directly associated with non-handaxe assemblages (Manzi et al., 2010; Manzi, 2016). But recent recognition of the increased variation in Eurasian Middle Pleistocene hominin types creates greater complexity and quite different taxonomic schema. Whereas Stringer (2012) argued for a narrower usage of heidelbergensis and a wider usage of neanderthalensis to include material like Sima de los Huesos and Steinheim, Manzi (2016) argues that the latter specimens should form part of a wider diagnosis of heidelbergensis, representing Homo heidelbergensis steinheimensis. In this context the association of putative Homo heidelbergensis fossils with handaxes at the pre-MIS11 site of Boxgrove is a topic which invites further research.

One way to interpret the archaeological complexity is to see the landscape and its resources as influencing human behaviour with the development of local traditions and their material outcomes. It can be suggested that during periods of stable environment, there was only small-scale movement (or 'drift') in human populations that became habituated within local landscapes. Adaptation to local circumstance created habits of behaviour, which became embedded in localised cultural practice. This created a complex mosaic of cultural groupings influenced as much by landscape setting as hominin type. It could be suggested that underpinning the different populations was a wider suite of technological practice, such as fire use (Mania, 1995; Gowlett et al., 2005; Molines et al., 2005; Preece et al., 2006; Roebroeks and Villa 2011), hunting with spears (Warren, 1911; Thieme, 1997; Schoch et al., 2015) and the use of hides (Voormolen, 2008). Given the lack of sites in central Europe 
during MIS 12, this interpretation would suggest that the first populations in MIS 11 to expand into this region lost the practice of handaxe manufacture due to a paucity of lithic raw material, but shared in the other technological advances used by populations in western and southern Europe. The explanation might also accommodate variation in hominin types with localised developments and more complex gene-flows between different regions (Dennell et al. 2011).

How can the British record be accommodated within this interpretation? If stable environments saw only a drift in population movement, then changes in climate or landscape may have caused larger scale movement of human groups. The comparatively narrow corridor into Britain would suggest that humans were more likely to arrive during times of environmental change and result in largerscale population movement. The first colonisers in MIS 11, perhaps from central Europe, probably reached Britain as climate changed to peak interglacial conditions during Holl. But what triggered the movement of the second group of colonisers, who arrived during an apparently stable climate at the end of Holl? The non-arboreal pollen (NAP) phase during Hollc has been recognised at a range of sites across northern Europe (Turner, 1970; Nitychoruk et al., 2005; Ashton et al., 2008; Candy et al., 2014). Whatever its cause, this rapid change in vegetation must have had an impact on human populations, possibly inducing large-scale movements in attempts to find more familiar environments. Was this the trigger for new human groups to move into Britain at the end of Holl, perhaps from western Europe, with handaxes as part of their cultural repertoire? The only archaeologically visible difference between the two populations was the presence or absence of handaxes, which was determined by cultural practice within the respective source areas. But it can be suggested that both groups were underpinned by a suite of other technological practices and behaviours, which were common to all late Middle Pleistocene hominins in Europe. Although Britain provides evidence of complex cultural groups, they can only be understood in a European context.

\section{Acknowledgements}

We would like to thank the Duke of Grafton and Andrew Blenkiron of the Euston Estate, and Edward, Richard and David Heading of East Farm for permission to excavate and for their full support and help during the excavation. For the excavation we are grateful to Mike Field, Erica van Hees, Peter Hoare, Sophie Hunter, Claire Lucas, Jordan Mansfield and Craig Williams, the student excavation teams from Britain and the Netherlands, and to David Switzer for logistical support. We also thank Craig Williams for production of Figures 1, 2 and 4 and an anonymous reviewer for helpful comments on the manuscript. Finally, we are grateful for financial support from the Calleva Foundation for the Pathways to Ancient Britain project, and for a Research Project Grant from the Leverhulme Trust for the Breckland Palaeolithic Project. 


\section{References}

Antoine $\mathrm{P}$, Limondin-Lozouet $\mathrm{N}$, Chaussé $\mathrm{C}$ et al. 2007. Pleistocene fluvial terraces from northern France (Seine, Yonne, Somme): synthesis and new results. Quaternary Science Reviews 26: 27012723.

Ashton NM. 1998. The technology of the flint assemblages. In Excavations at the Lower Palaeolithic Site at East Farm, Barnham, Suffolk, 1989-94, Ashton NM, Lewis SG, Parfitt SA (eds). British Museum Occasional Paper 125: London; 205-235.

Ashton NM, Lewis SG, Parfitt SA (eds). 1998. Excavations at the Lower Palaeolithic Site at East Farm, Barnham, Suffolk, 1989-94. British Museum Occasional Paper 125: London.

Ashton NM, Lewis SG, Parfitt SA et al. 2005. Excavations at the Lower Palaeolithic site at Elveden, Suffolk, UK. Proceedings of the Prehistoric Society 71: 1-61.

Ashton NM, Lewis SG, Parfitt SA et al. 2008. New evidence for complex climate change in MIS 11 from Hoxne, UK. Quaternary Science Reviews 27: 652-668.

Ashton NM, McNabb J, Irving BG et al. 1994. Contemporaneity of Clactonian and Acheulian flint industries at Barnham, Suffolk. Antiquity 68: 585-589.

Barsky D. 2013. The Caune de l'Arago stone industries in their stratigraphical context. Comptes Rendus Palevol 12: 305-325.

Breuil H. 1932. Les industries á éclat de paléolithique ancient I: Le Clactonien. Préhistoire 1: 148-157.

Candy I, Schreve DC, Sherriff J et al. 2014. Marine Isotope Stage 11: Palaeoclimates, palaeoenvironments and its role as an analogue for the current interglacial. Earth-Science Reviews 128: $18-51$.

Clarke WG. 1913. Some Barnham palaeoliths. Proceedings of the Prehistoric Society of East Anglia 1: 300-3.

Collins D. 1969. Culture traditions and environment of early man. Current Anthropology 10: 267-316.

Dennell RW, Martinón-Torres M, Bermúdez de Castro JM. 2011. Hominin variability, climatic instability and population demography in Middle Pleistocene Europe. Quaternary Science Reviews 30: 1511-1524.

Fluck HL. 2011. Non-biface assemblages in Middle Pleistocene Western Europe. A comparative study. $\mathrm{PhD}$ thesis, University of Southampton.

Gowlett JAJ, Hallos J, Hounsell S et al. 2005. Beeches Pit - archaeology, assemblage dynamics and early fire history of a Middle Pleistocene site in East Anglia, UK. Eurasian Prehistory 3: 3-38.

Hijma, MP, Cohen, KM, Roebroeks W et al. 2012. Pleistocene Rhine-Thames landscapes: geological background for hominin occupation of the southern North Sea region. Journal of Quaternary Science 27: 17-39 
Hunt CO. 1998. The palynology of the Barnham sequence. In Excavations at the Lower Palaeolithic Site at East Farm, Barnham, Suffolk, 1989-94, Ashton NM, Lewis SG, Parfitt SA (eds). British Museum Occasional Paper 125: London; 153-163.

Kemp RA. 1998. Micromorphology of the Area I sequence at East Farm, Barnham. In Excavations at the Lower Palaeolithic Site at East Farm, Barnham, Suffolk, 1989-94, Ashton NM, Lewis SG, Parfitt SA (eds). British Museum Occasional Paper 125: London; 83-89.

Kerney MP. 1971. Interglacial deposits at Barnfield Pit, Swanscombe, and their molluscan fauna. Journal of the Geological Society of London 127: 69-93.

Lautridou J-P, Verron G. 1970. Paléosols et lœss de Saint-Pierre-lès-Elbeuf. Bulletin de l'Association Française pour l'étude du Quaternaire 2: 145-165.

Lewis SG. 1998. Quaternary geology of East Farm brick pit, Barnham and the surrounding area. In Excavations at the Lower Palaeolithic Site at East Farm, Barnham, Suffolk, 1989-94, Ashton NM, Lewis SG, Parfitt SA (eds). British Museum Occasional Paper 125: London; 23-78.

Limondin-Lozouet N, Antoine P, Bahain J-J et al. 2015. North-West European MIS 11 malacological successions: A framework for the timing of Acheulean settlements. Journal of Quaternary Science 30: 702-712.

Limondin-Lozouet N, Nicoud E, Antoine P et al. 2010. Oldest evidence of Acheulean occupation in the Upper Seine valley (France) from an MIS 11 tufa at La Celle. Quaternary International 223-224: 299-311.

Mania D. 1995. The earliest occupation of Europe: The Elbe-Saale Region (Germany). In The Earliest Occupation of Europe, Roebroeks W, van Kolfschoten, T (eds). Leiden: University of Leiden and European Science Foundation; 85-102

Manzi G, Magri D, Milli S et al. 2010. The new chronology of the Ceprano calvarium (Italy). Journal of Human Evolution 59: 580-5.

Manzi G. 2016. Humans of the Middle Pleistocene: The controversial calvarium from Ceprano (Italy) and its significance for the origin and variability of Homo heidelbergensis. Quaternary International 411: 254-261.

McNabb J. 1992. The Clactonian: British Lower Palaeolithic Flint Technology in Biface and Non-biface Assemblages. PhD Thesis, University of London.

McNabb J. 2007. The British Lower Palaeolithic. Stones in Contention. Routledge: London.

Meijer T, Preece RC. 1995. Malacological evidence relating to the insularity of the British Isles during the Quaternary. In Island Britain: A Quaternary Perspective, Preece RC (ed.), Geological Society Special Publication 96: London; 89-110.

Molines N, Monnier J-L, Hinguant S et al. 2005. L'Acheuléen de l'ouest de la France: apports du site de Menez Dregan I (Plouhinec, Finistère, France). In Les Premiers Peuplements en Europe, Molines N, Moncel M-H, Monnier J-L (eds). BAR International Series: Oxford; 533-544. 
Moncel M-H, Ashton NM, Lamotte A et al. 2015. North-west Europe early Acheulian. Journal of Anthropological Archaeology 40: 302-331.

Nitychoruk J, Bińka K, Hoefs J et al. 2005. Climate reconstruction for the Holsteinian Interglacial in eastern Poland and its comparison with isotopic data from Marine Isotope Stage 11. Quaternary Science Reviews 24: 631-644.

Parfitt SA, 1998a. Palaeoecological summary of Unit 5c. In Excavations at the Lower Palaeolithic Site at East Farm, Barnham, Suffolk, 1989-94, Ashton NM, Lewis SG, Parfitt SA (eds). British Museum Occasional Paper 125: London; 167-171.

Parfitt SA. 1998b. The interglacial mammalian fauna from Barnham. In Excavations at the Lower Palaeolithic Site at East Farm, Barnham, Suffolk, 1989-94, Ashton NM, Lewis SG, Parfitt SA (eds). British Museum Occasional Paper 125: London; 111-147.

Paterson TT. 1937. Studies on the Palaeolithic succession in England No. 1, the Barnham sequence. Proceedings of the Prehistoric Society 3: 87-135.

Preece RC, Penkman KEH. 2005. New faunal analyses and amino acid dating of the Lower Palaeolithic site at East Farm, Barnham, Suffolk. Proceedings of the Geologists' Association 116: 363-377.

Preece RC, Gowlett JAJ, Parfitt SA et al. 2006. Humans in the Hoxnian: habitat, context and fire use at Beeches Pit, West Stow, Suffolk, UK. Journal of Quaternary Science 21: 485-496.

Preece RC, Parfitt SA, Bridgland DR et al. 2007. Terrestrial environments during MIS 11: evidence from the Palaeolithic site at West Stow, Suffolk, UK. Quaternary Science Reviews 26: 1236-1300.

Roebroeks W, Villa P. 2011. On the earliest evidence for habitual use of fire in Europe. Proceedings of the National Academy of Science 108: 5209-5214.

Schoch WH, Bigga G,Böhner U et al. 2015. New insights on the wooden weapons from the Paleolithic site of Schöningen. Journal of Human Evolution 89: 214-225.

Smith RA, Dewey H. 1913. Stratification at Swanscombe: report on excavations made on behalf of the British Museum and H.M. Geological Survey. Archaeologia 64: 177-204.

Stringer CB. 2011. The changing landscapes of the earliest human occupation of Britain and Europe. In The Ancient Human Occupation of Britain, Ashton NM, Lewis SG, Stringer CB (eds). Elsevier: Amsterdam; 1-10.

Stringer CB. 2012. The status of Homo heidelbergensis (Schoetensack 1908). Evolutionary Anthropology 21: 101-107.

Thieme H. 1997. Lower Paleolithic hunting spears from Germany. Nature 385: 807-810.

Turner C. 1970. Middle Pleistocene deposits at Marks Tey, Essex. Philosophical Transactions of the Royal Society of London B257: 373-437.

Villa P. 1991. Middle Pleistocene prehistory in southwestern Europe: the state of our knowledge and ignorance. Journal of Anthropological Research 47: 193-213. 
Voinchet P, Moreno D, Bahain J-J et al. 2015. New chronological data (ESR and ESR/U-series) for the earliest Acheulean sites of northwestern Europe. Journal of Quaternary Science 30, 610-622.

Voormolen B. 2008. Ancient Hunters, Modern Butchers. Schöningen 13II-4, a kill-butchery site dating from the northwest European Lower Palaeolithic. PhD thesis, University of Leiden.

Warren SH. 1926.The classification of the Lower Palaeolithic with especial reference to Essex. The South-Eastern Naturalist 31: 38-50.

Wenban-Smith FF. 1998. Clactonian and Acheulian industries in Britain: their chronology and significance reconsidered. In Ashton NM, Healy F, Pettitt P (eds) Stone Age Archaeology: Essays in honour of John Wymer. Oxbow Monograph 102 \& Lithic Studies Society Occasional Paper 6. Oxbow Books: Oxford; 90-97.

Wenban-Smith FF (ed.) 2013. The Ebbsfleet Elephant. Excavations at Southfleet Road, Swanscombe in advance of High Speed 1, 2003-4. Oxford Archaeology: Oxford.

West RG. 1956. The Quaternary deposits at Hoxne, Suffolk. Philosophical Transactions of the Royal Society of London B239: 265-356.

White MJ. 2000. The Clactonian question: on the interpretation of core and flake assemblages in the British Isles. Journal of World Prehistory 14: 1-63.

White MJ, Schreve DC. 2000. Island Britain - peninsula Britain: palaeogeography, colonisation and the Lower Palaeolithic settlement of the British Isles. Proceedings of the Prehistoric Society 66: 1-28.

White TS, Preece RC, Whittaker JE. 2013. Molluscan and ostracod successions from Dierden's Pit, Swanscombe: insights into the fluvial history, sea-level record and human occupation of the Hoxnian Thames. Quaternary Science Reviews 70: 73-90.

Whitaker W, Woodward HB, Bennet FJ et al. 1891. The Geology of parts of Cambridgshire and of Suffolk. Memoirs of the Geological Survey of England and Wales, Explanation of Sheet 51NE and part of 51NW.

Wymer JJ. 1968. Lower Palaeolithic Archaeology in Britain as represented by the Thames Valley. John Baker: London.

Wymer JJ. 1985. Palaeolithic Sites of East Anglia. Geo Books: Norwich. 


\section{Figures}

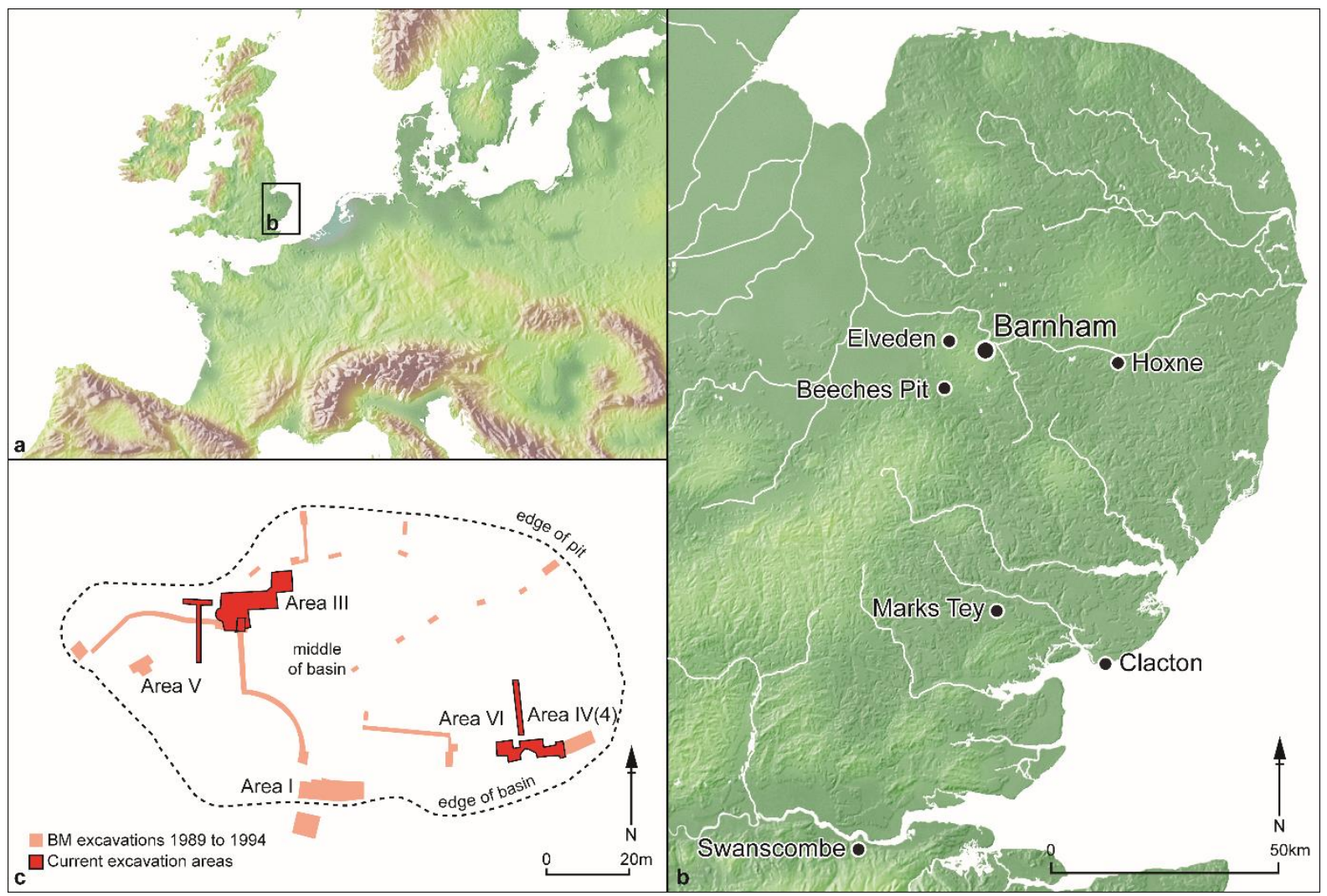

Figure 1. Location maps of current excavations within (a) Europe, (b) East Anglia and (c) East Farm Pit, Barnham. 


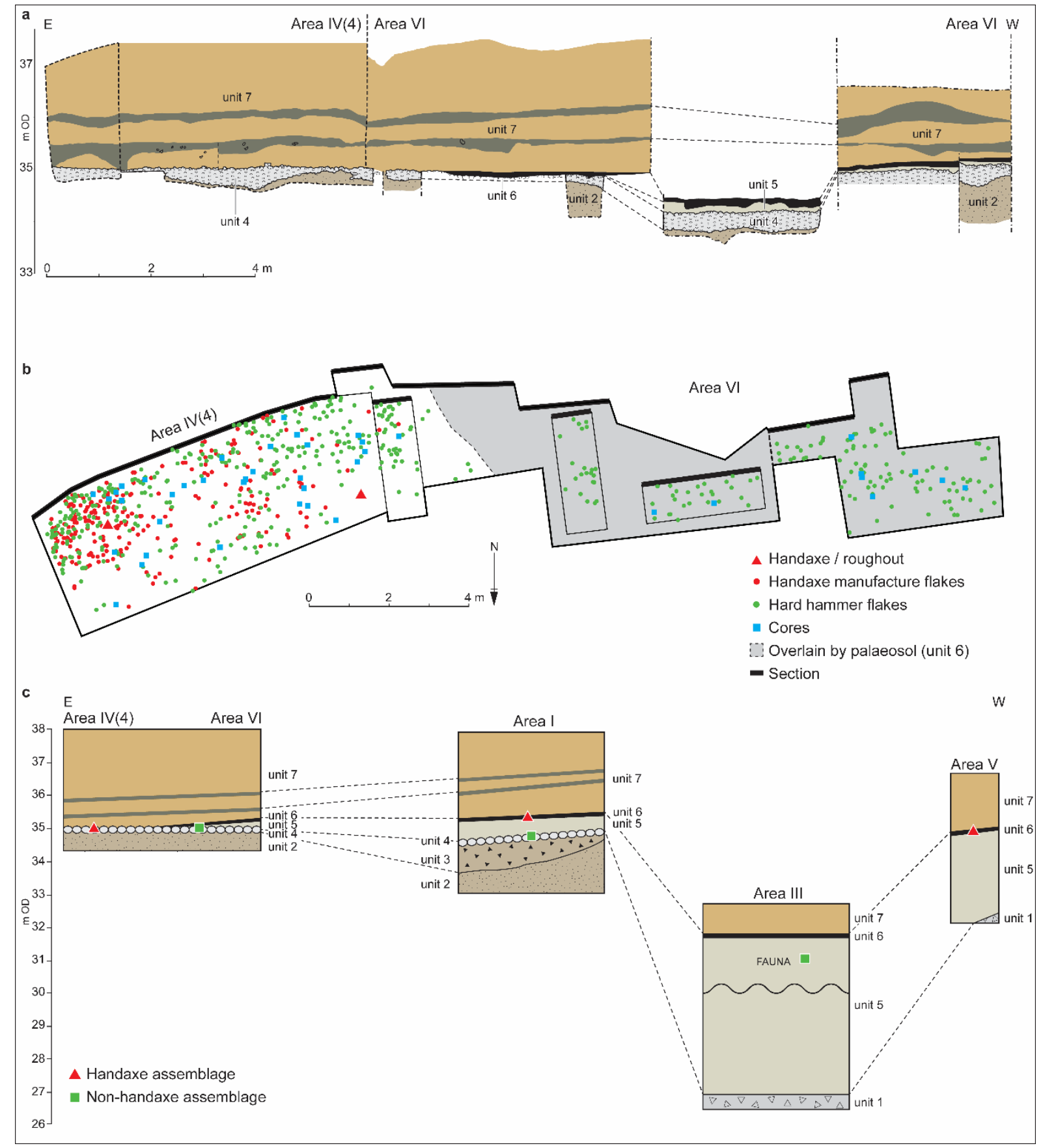

Figure 2. East Farm Pit, Barnham. (a) Geological section in Areas IV(4) and VI; (b) plan of Areas IV(4) and $\mathrm{VI}$ showing distribution of handaxe and non-handaxe artefacts and the lateral extent of unit 6 ; (c) schematic cross-section between Areas IV(4), VI, I, III and V showing the stratigraphic position of the handaxe and non-handaxe assemblages. The geological sediments are: unit 1 - till; unit 2 -glacial sands and gravels; unit 3 - debris flow diamictons; unit 4-lag gravel; unit 5 -silt; unit 6 - palaeosol; unit 7 - brown silty clay ('brickearth'). 


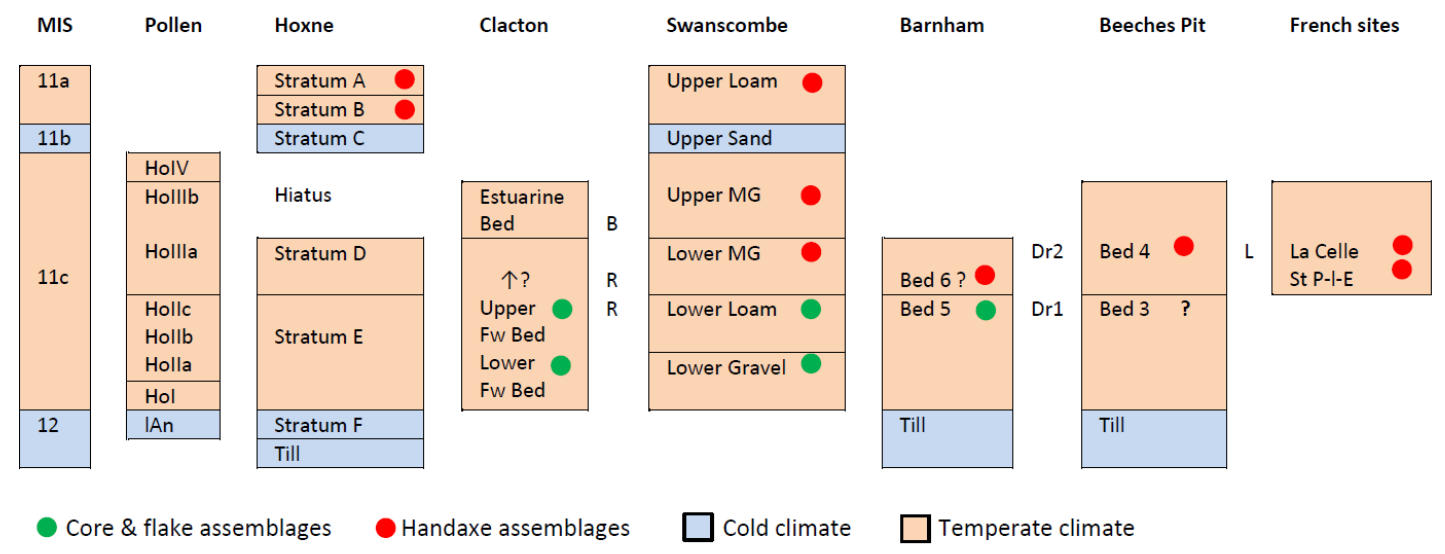

Figure 3. Suggested correlation of British and French sites using stratigraphy, palynology and biostratigraphy (based on Preece and Penkman, 2005; Ashton et al., 2008; White et al., 2013). Fw Bed = Freshwater Bed; MG = Middle Gravel; St P-I-E = St Pierre-les-Elbeuf; B = Brackish molluscan fauna; $\mathrm{R}=$ Rhenish molluscan fauna; $\operatorname{Dr} 1=$ the mollusc Discus rotundatus; $\operatorname{Dr} 2=$ the mollusc Discus ruderatus; $\mathrm{L}=$ Lyrodiscus molluscan fauna. 


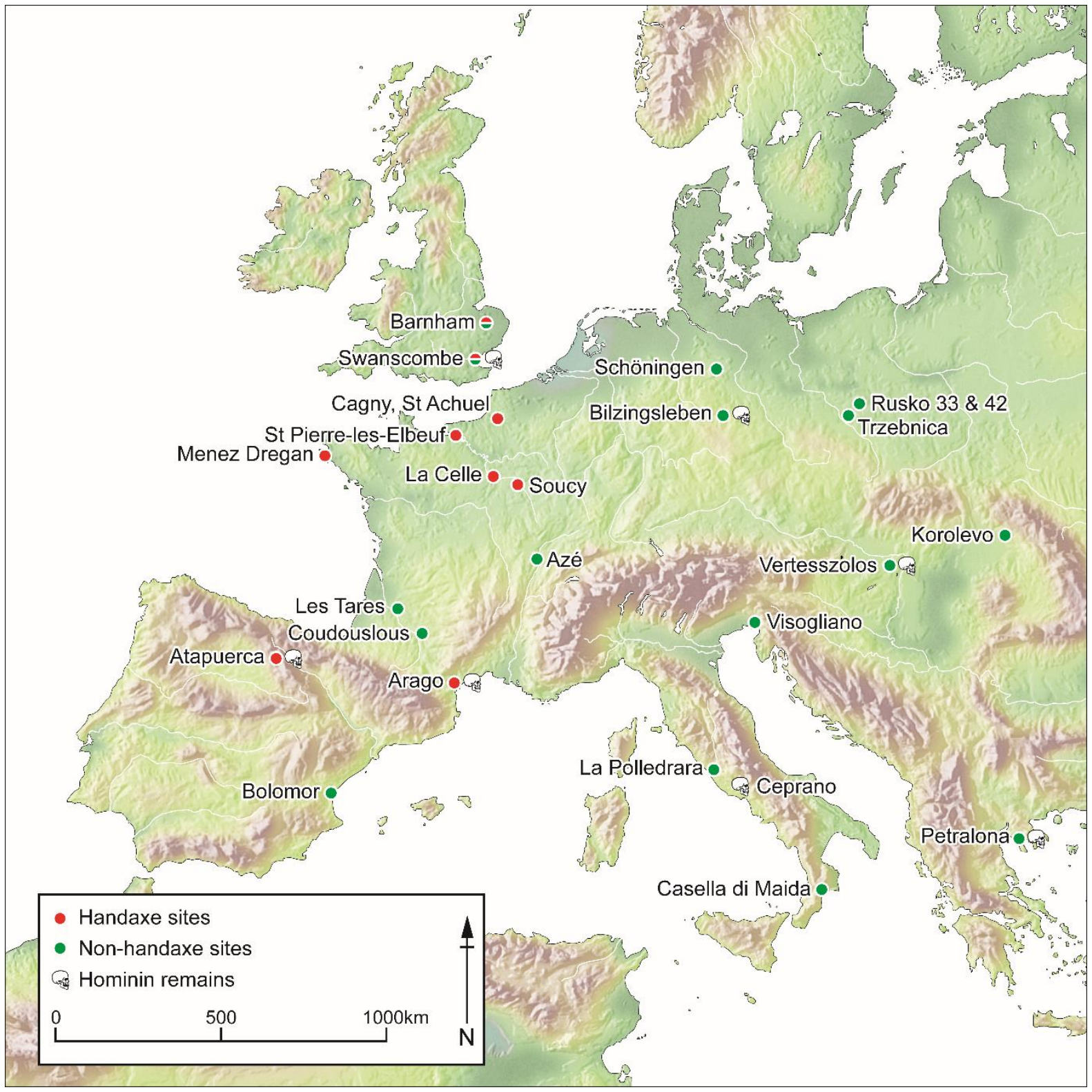

Figure 4. European distribution of non-handaxe sites and key handaxe sites attributed to MIS 11-9 (partly based on Fluck 2011). Sites with hominin remains are also shown. 